\title{
FEASIBILITY ANALYSIS OF THE USE OF LIGHT AND MEDIUM TRUCKS IN TIMBER TRANSPORT IN RURAL PROPERTIES ${ }^{1}$
}

\author{
Stanley Schettino ${ }^{2 *}$, Luciano José Minette ${ }^{3}$, Carolina Freitas Schettino ${ }^{4}$ and Isabela Dias Reboleto ${ }^{5}$
}

\footnotetext{
${ }^{1}$ Received on 10.08.2018 accepted for publication on 14.12.2018

${ }^{2}$ Universidade Federal de Minas Gerais, Instituto de Ciências Agrárias, Montes Claros ,Minas Gerais,Brasil . E-mail: <schettino@ufmg.br> .

${ }^{3}$ Universidade Federal de Viçosa, Departamento de Engenharia de Produção e Mecânica, Viçosa,Minas Gerais,Brasil. E-mail: $<$ minette@ufv.br>.

${ }^{4}$ Universidade Federal de Santa Catarina, Graduando em Engenharia de Transporte e Logística. E-mail:<carolinafschettino@gmail.com>.

${ }^{5}$ Universidade Federal de Viçosa, Programa de Pós-Graduação em Ciência Florestal, Viçosa,Minas Gerais,Brasil. E-mail:

<isabela.reboleto@gmail.com>.

*Corresponding author.
}

\begin{abstract}
Aiming to analyze the economic-financial feasibility of the use of light and medium trucks in the transport of the timber produced by small farmers within the process of forest production, two types of light trucks and two of medium trucks were evaluated in 14 rural properties in the State of Espírito Santo. Considering the transport cycles, distances, productivity of the forests, acquisition values, load capacity and fuel consumption of each truck, in addition to the cost of opening roads, nonlinear regression equations were adjusted to estimate the timber transport cost in the different scenarios evaluated. Transport costs were included in the cash flow of the forest production process, and the internal rate of return and net present value for all combinations were evaluated. The results configured the light truck in the $6 \times 2$ version as the most economically viable alternative for timber transport, with $125 \mathrm{~km}$ being the maximum feasible distance in forests with productivity up to $250 \mathrm{~m}^{3} / \mathrm{ha}$. In forests with productivity above $300 \mathrm{~m}^{3} / \mathrm{ha}$, the medium truck in the $6 \times 2$ version proved to be the most viable economic alternative in distances over $150 \mathrm{~km}$. The light and medium trucks in the $4 \times 2$ version did not prove to be the best economic alternative in any of the evaluated situations. It is concluded that light trucks are an economically viable alternative for timber transport, in order to ensure the profitability and sustainability of the forestry business in small rural properties.
\end{abstract}

Keywords: Cost management; Forest logistics; Transport vehicles.

\section{ANALLISE DA VIABILIDADE DE UTILIZAÇÃO DE CAMINHÕES LEVES E MÉDIOS NO TRANSPORTE DE MADEIRA EM PROPRIEDADES RURAIS}

\begin{abstract}
RESUMO - Visando analisar a viabilidade econômico-financeira da utilização de caminhões leves e médios no transporte da madeira produzida por pequenos produtores rurais dentro do processo de produção florestal, foram avaliados dois tipos de caminhões leves e dois de caminhões médios em 14 propriedades rurais no Estado do Espirito Santo. Considerando os ciclos de transporte, as distâncias, as produtividades das florestas, os valores de aquisição, a capacidade de carga e o consumo de combustível de cada caminhão, além do custo de abertura de estradas, foram ajustadas equações de regressão não linear de forma a estimar o custo de transporte de madeira nos diferentes cenários avaliados. Os custos de transporte foram inseridos no fluxo de caixa do processo de produção florestal, tendo sido avaliados a taxa interna de retorno e o valor presente líquido para todas as combinações. Os resultados configuraram o caminhão leve na versão $6 \times 2$ como a alternativa mais viável economicamente para o transporte da madeira, sendo $125 \mathrm{~km}$ a distância máxima viável, em florestas com produtividades até $250 \mathrm{~m}^{3} / \mathrm{ha}$. Em florestas com produtividades acima de $300 \mathrm{~m}^{3} / \mathrm{ha}$, o caminhão médio na versão $6 x 2$ demonstrou ser a alternativa econômica mais viável em distâncias a partir de $150 \mathrm{~km}$. Os caminhões leve e médio na versão $4 x 2$ não evidenciaram ser a melhor alternativa econômica em nenhuma das situações avaliadas. Conclui-se que os caminhões leves são uma alternativa economicamente viável para o transporte da madeira, de forma a assegurar a rentabilidade e a sustentabilidade do negócio florestal em pequenas propriedades rurais.
\end{abstract}

Palavras-Chave: Logística florestal; Gestão de custos; Veículos de transporte. 


\section{INTRODUCTION}

Timber production in small rural properties has been gaining impulse in recent years, from both government policies and private sector (investors and large forest-based enterprises) incentives. However, in different regions of the country, timber producers have not been achieving the expected economic results. The costs of transporting timber to the consumer units or to the intermediate yards have been pointed out as the most impacting on the activity allied to the forest harvesting activities (Basso et al., 2012).

The forest transport is basically the movement of the timber from the yard or the roadside to the consumer, processing or storage unit. Among all the possible forms of transport, the most used in Brazil is the road type, even though it is not competitive when compared to railway or waterway modes (Deimling et al., 2016). This choice is due to the national history of the transport matrix, predominantly road, and some factors contribute to this situation: the extensive road network available in Brazil, the offer of different types of vehicles and low installation value when compared to other existing modes (Machado et al., 2009).

Studies on timber transport have generally considered the reality of large forest enterprises. Concentrating in the development and use of heavy and extra-heavy trucks with load capacity above 30 tonnes and high values of acquisition and maintenance (Oliveira et al., 2007; Alves et al., 2013). This reality is very different from that faced by small timber producers when it comes to transport. Furthermore, it is important to consider that the impact of this stage cost can significantly affect the economic result of the activity of planted forests (Moreira et al., 2017).

Several studies have pointed out that larger trucks have lower transport costs, among which, predominantly, bitrem, tritrem and road train, all with load capacity greater than $45 \mathrm{t}$ (Silva et al., 2007; Savi et al., 2012; Alves et al., 2013; Lopes et al., 2016; Moreira et al., 2017). However, such compositions require large volumes of timber and road patterns that are not found in the study region (topographical constraints) and in other similar regions. This technically preclude its use by small forest producers, restricting the use of freight value analysis in isolation. Thus, in order to evaluate the feasibility of using different trucks, an analysis of the investment as a whole is required, including

Revista Árvore. 2018;42(6):e420608 the transport cost along with the main variables of the forest business, such as implantation costs, forest maintenance, harvest and opening of roads, interest rates, forest production and timber sale price (Silva et al., 2007).

The design of a timber transport project that is adequate to the reality of small-scale timber producers, with the use of smaller trucks, has the potential to reduce acquisition, maintenance and investment costs in roads within the properties. Thus, it is shown as an alternative capable of increasing the profitability of the forest business and guarantee its safety and sustainability in economic terms.

Given this scenario, considering the factors forest productivity and transport distance, this study aimed to perform an analysis of the economic-financial feasibility of the use of light and medium trucks in the transport of the timber produced by small farmers within the forest production process.

\section{MATERIALS AND METHODS}

\subsection{Characterization of the study area}

This study was developed with data collected from 14 rural properties (with areas varying from 17.5 to $58.3 \mathrm{ha}$ ) in a region in the South of Espirito Santo State, with a high concentration of forest fostering projects linked to a pulp producer enterprise. The projects, in their totality with Eucalyptus plantations, had average productivity from 150 to $300 \mathrm{~m}^{3} /$ ha, according to the results of forest inventories carried out on the properties.

The region, located between the parallels $20^{\circ}$ and $21^{\circ}$ south of the Equator Line and the meridians $40^{\circ}$ and $42^{\circ}$ west of the Greenwich meridian, has the following characteristics: altitude varying from 250 to $1,100 \mathrm{~m}$; mean annual temperature of $22.2^{\circ} \mathrm{C}$, ranging from 16.9 to $29.0^{\circ}$; climate warm and humid in the summer and dry in the winter, average annual rainfall of 1,240 $\mathrm{mm}$; relief varies from strongly wavy to hilly and, according to Fiedler et al. (2011), the slope of the terrains in the region varies between 28 and $43 \%$. Data were collected between October and December 2016, with trucks transporting timber from rural properties to a timber receiving yard.

The transport distances varied from 10 to $150 \mathrm{~km}$. The roads in the study region are divided into unpaved without primary coating $(21.0 \%)$, unpaved with primary coating (25.0\%) and paved with carriageway (54\%). 
According to the definition of the National Institute of Colonization and Agrarian Reform (INCRA), small farms are those whose total area varies from 1 to 4 fiscal modules, which in the region of the study corresponds to properties with area between 15 and 100 hectares (INCRA, 2017).

\subsection{Trucks evaluated}

The types of trucks evaluated in this study, as well as their specifications, are listed in Table 1.

In order to determine the average times and speeds of the trips of the trucks, as well as the number of trips per day, a study of time and movements of the transport by the continuous time method was carried out, using a digital timer and a form for the recording of the data. Under the conditions of this study, the operational cycle of transportation was subdivided into the following partial components: empty trip; loading; loaded trip; unloading; and breaks and interruptions.

\subsection{Analysis variables}

Table 2 presents the total costs, distributed according to the operations required to implement and maintain one hectare of eucalyptus forest, given the conditions of the studied area, considering a shallow cut at 7 years and subsequent regrowth conduction, with final shallow cut at 14 years.

The costs for opening roads within the properties were obtained after applying the methodology proposed by Silva et al. (2014), considering an average density of $100 \mathrm{~m} / \mathrm{ha}$, as presented in the study by Corrêa et al. (2006). For light trucks (C1 and C2), road opening was considered using a $110 \mathrm{CV}$ agricultural tractor with front blade, the most used model by forest producers in the study region ( 2 hours of machine per hectare).
In the case of medium trucks ( $\mathrm{C} 3$ and $\mathrm{C} 4$ ), the road opening was evaluated using a track tractor of 125 $\mathrm{CV}$ and 13 tonnes total weight, also equipped with a front blade (3 hours of machine per hectare). In all cases, new tractors and implements were considered.

The costs (road opening, loading and freight) were converted into costs per hectare $(\mathrm{R} \$ / \mathrm{ha})$ and grouped to analyze the different variables, assuming that the timber transport operation involves these three activities and is sensitive to variations in each one of them. Productivity estimates of the stands from 150 to 300 $\mathrm{m}^{3} / \mathrm{ha}$ (with intervals of $50 \mathrm{~m}^{3} / \mathrm{ha}$ ) were used, in order to allow the simulations necessary for the objectives of this study to be consistent with the reality of the evaluated region.

\subsection{Timber transport cost}

The timber transport cost $\left(\mathrm{R} \$ / \mathrm{m}^{3}\right)$ was calculated for each property using the Cost Simulation Spreadsheet of the Load Transport Operation, developed by ANTT - National Agency of Land Transportation (ANTT, 2017), which considers all fixed and variable costs simulating different operating conditions, such as truck acquisition value, number of hours worked per month, vehicle average speed, number of trips per day, fuel consumption and transport distance. In all the situations evaluated the dedicated transport was considered, that is, the trucks only transport timber and the return trips are always without load. Also, in order to allow economic feasibility analyses, freight values were converted to transport cost per hectare $(\mathrm{R} \$ / \mathrm{ha})$, for each combination of distance and productivity of the forests.

In order to establish a relationship between the timber transport cost $(\mathrm{R} \$ / \mathrm{ha})$ and the study variables, and with the sets of data on transport distance, forest productivity (independent variables) and timber transport

Table 1 - Specifications of the trucks used to evaluate the timber transport costs in small rural properties.

Tabela 1 - Especificações dos caminhões utilizados para avaliação dos custos de transporte de madeira em pequenas propriedades rurais.

\begin{tabular}{lccccccc}
\hline Truck & Type & Configuration & $\begin{array}{c}\text { Strength } \\
(\mathrm{CV})^{1 /}\end{array}$ & $\begin{array}{c}\text { Diesel } \\
\text { Consumption } \\
(\mathrm{Km} / \mathrm{l})^{1 /}\end{array}$ & $\begin{array}{c}\text { Load } \\
\text { Capacity } \\
(\mathrm{t}){ }^{1 /}\end{array}$ & $\begin{array}{c}\text { Average } \\
\text { Speed } \\
(\mathrm{Km} / \mathrm{h})^{2 /}\end{array}$ & $\begin{array}{c}\text { Aquisition } \\
\text { Value } \\
(\mathrm{R} \$)^{3 /}\end{array}$ \\
\hline C1 & Light & $4 \times 2$ & 160 & 5.5 & 6.15 & 50.0 & $140,200.00$ \\
C2 & Light & $6 \times 2$ & 189 & 5.0 & 7.95 & 45.0 & $150,828.00$ \\
C3 & Medium & $4 \times 2$ & 185 & 4.0 & 7.40 & 45.0 & $158,569.00$ \\
C4 & Medium & $6 \times 2$ & 238 & 2.5 & 12.85 & 45.0 & $190,710.00$ \\
\hline
\end{tabular}

${ }^{1 /}$ Data of manufacturers, discounting the net weight.

${ }^{2 /}$ Considering the complete cycle (one-way journey loaded and return empty), obtained from the study of times and movements.

${ }^{3 /}$ New trucks, FIPE - Institute of Economic Research Foundation Table base (FIPE, 2017). 
Table 2 - Formation and harvesting costs of eucalyptus forests in the study area, as well as data used in the financial analyzes. Tabela 2 - Custos de formação e colheita de florestas de eucalipto na área de estudo, bem como dados utilizados nas análises financeiras.

\begin{tabular}{lc}
\hline Items & Values \\
\hline Implementation cost & $\mathrm{R} \$ 1,395.00 / \mathrm{ha}$ \\
Maintainance cost - year 1 & $\mathrm{R} \$ 789.00 / \mathrm{ha}$ \\
Maintainance cost - years 2 to 6 & $\mathrm{R} \$ 275.00 / \mathrm{ha}$ \\
Administrative expenses- years 1 to 7 & $\mathrm{R} \$ 43.00 / \mathrm{ha}$ \\
Protection and insurance - years 1 to 7 & $\mathrm{R} \$ 138.00 / \mathrm{ha}$ \\
Cost of regrowth conduction - year 8 & $\mathrm{R} \$ 837.00 / \mathrm{ha}$ \\
Maintainance cost - year 9 & $\mathrm{R} \$ 474.00 / \mathrm{ha}$ \\
Maintainance cost - years 10 to 14 & $\mathrm{R} \$ 165.00 / \mathrm{ha}$ \\
Administrative expenses - years 8 to 14 & $\mathrm{R} \$ 43.00 / \mathrm{ha}$ \\
Protection and insurance - years 8 to 14 & $\mathrm{R} \$ 138.00 / \mathrm{ha}$ \\
Interest rate & $8 \% \mathrm{a} . \mathrm{a}$. \\
Harvesting cost ${ }^{1 /}$ & $\mathrm{R} \$ 16.00 / \mathrm{m}^{3}$ \\
Loading cost & $\mathrm{R} \$ 3.50 / \mathrm{m}^{3}$ \\
Cost of opening roads for C1 and C2 trucks & $\mathrm{R} \$ 183.78 / \mathrm{ha}$ \\
Cost of opening roads for C3 e C4 trucks & $\mathrm{R} \$ 826.68 / \mathrm{ha}$ \\
Price of the timber delivered at the yard & $\mathrm{R} \$ 100.00 / \mathrm{m}^{3}$ \\
\hline
\end{tabular}

${ }^{1 /}$ Average values practiced in the study region.

Note: For this study, the land value was not considered.

total cost per hectare (dependent variable), applying techniques of nonlinear regression (Seber and Wild, 2003), the following model was adjusted for each type of truck:

$$
\operatorname{Ln}(Y)=\beta_{0}+X_{1}^{\beta_{1}}+X_{2}^{\beta_{2}}+\varepsilon_{i}
$$

on which:

$\mathrm{Ln}=$ natural logarithm; $\mathrm{Y}=$ dependent variable; $X_{1}$ and $X_{2}=$ independent variables; $\beta_{0}$ and $\beta_{1}=$ parameters of the models; and $\varepsilon_{\mathrm{i}}=$ random error.

The adjusted equations were evaluated through the coefficient of determination $\left(\mathrm{R}^{2}\right)$, the coefficient of variation $(\mathrm{CV} \%)$ and the correlation coefficient between the observed and predicted squared values $\left(\mathrm{R}_{\mathrm{yw}}{ }^{2}\right)$, using STATISTICA software for Windows (Statsoft Inc., 1995).

It was evaluated whether the costs of timber transport operation (including the costs of timber transport, opening roads and loading) using the trucks involved in the study are associated with the transport distance and the volumetry of the forests. For this, the degree of association was obtained by analyzing the Pearson correlation coefficient matrix ( $r$ ) and by the " $t$ " test at $5 \%$ and $1 \%$ probability.

Only to present the results, distances ranging from 25 to $150 \mathrm{~km}$ with intervals of $25 \mathrm{~km}$ were considered, and the transport total costs were obtained from the

Revista Árvore. 2018;42(6):e420608 application of the adjusted equations and added to the costs of opening roads and loading.

\subsection{Economic analysis}

In order to meet the objectives of this study, the economic analysis considered the total costs of the project (implantation, harvesting, loading, opening of roads and timber transport), as well as revenues from the sale of timber over a planning horizon of 14 years (two rotations). Considering each type of truck evaluated and for each combination of forest productivity and transport distance, after obtaining the cash flow containing the inflows and outflows along the planning horizon, the economic analysis was performed based on the criteria Net Present Value (NPV) and Internal Rate of Return (IRR).

The NPV represents the difference between the present value of the revenues and the present value of the costs, at a given discount rate, being obtained by the following equation:

$$
N P V=\sum_{\mathrm{j}=0}^{\mathrm{n}} \mathrm{R}_{\mathrm{j}}(1+\mathrm{i})^{-\mathrm{j}}-\sum_{\mathrm{j}=0}^{\mathrm{n}} \mathrm{C}_{\mathrm{j}}(1+\mathrm{i})^{-\mathrm{j}}
$$

on which:

$\mathrm{NPV}=$ net present value $(\mathrm{R} \$ / \mathrm{ha}) ; \mathrm{R}=$ revenue in time period $\mathrm{j}(\mathrm{R} \$ / \mathrm{ha}) ; \mathrm{C}=$ cost in time period $\mathrm{j}$ $(\mathrm{R} \$ / \mathrm{ha}) ; \mathrm{i}=$ interest rate $(\%$ per year $) ; \mathrm{j}=$ period of 
occurrence of revenue or cost (years); and $n=$ duration of the project in years or in number of time periods.

In turn, the IRR is the interest rate that equals the present value of revenues to the present value of costs, that is, it is reached when the NPV of the cash flow equals zero. It can also be understood as the percentage rate of return on invested capital, and its formula is given by:

$$
\sum_{j=0}^{n} R_{j}(1+I R R)^{-j}=\sum_{j=0}^{n} C_{j}(1+I R R)^{-j}
$$

on which:

$\mathrm{IRR}=$ internal rate of return (\% per year $) ; \mathrm{R}=$ revenue in time period $\mathrm{j}(\mathrm{R} \$ / \mathrm{ha}) ; \mathrm{C}=$ cost in time period $\mathrm{j}(\mathrm{R} \$ / \mathrm{ha}) ; \mathrm{j}=$ period of occurrence of revenue or cost (years); and $\mathrm{n}=$ duration of the project in years or in number of time periods.

\section{RESULTS}

The equations adjusted for the data sets presented a good quality of adjustment, considering the estimation of the coefficients of determination $\left(\mathrm{R}^{2}\right)$, the coefficients of variation $(\mathrm{CV} \%)$, the correlation coefficients between the observed and predicted squared values $\left(\mathrm{R}_{\mathrm{yw}}{ }^{2}\right)$ and the Pearson correlation coefficient (r), presented in Table 3 .

The observation of these results allows to determine that the positive sign of the Pearson correlation coefficient (r) with the variable transport distance $(\mathrm{P}<0.05)$ evidences the increase in timber transport cost with increasing distance, and this correlation can be considered strong given that the values are close to unity. On the other hand, the significance values presented for the correlation with forest volumetrics $(\mathrm{P}<0.05)$ make it clear that although this variable has a moderate positive correlation they indicate significant interference on the timber transport cost.

The timber transport cost for the different types of trucks evaluated, considering the variations in forest productivity and transport distances, was estimated by the adjusted nonlinear regression equations, including the costs of the opening roads and loading activities (Table 4).

The results of the economic analysis for each combination of forest productivity and transport distances, after obtaining the cash flow containing the inflows and outflows along the planning horizon, are presented in Table 5.

The results show that the economic result of the forestry business is more attractive with the use of the $\mathrm{C} 2$ truck for timber transport, with the feasibility being related to the productivity of the forests. In forests with productivity up to $150 \mathrm{~m}^{3} /$ ha the maximum viable transport distance is $75 \mathrm{~km}$; in those with productivity of $200 \mathrm{~m}^{3} / \mathrm{ha}$, this distance increases to $100 \mathrm{~km}$; and in those with $205 \mathrm{~m}^{3} / \mathrm{ha}$, up to $125 \mathrm{~km}$. Furthermore, in forests with productivity in the order of $300 \mathrm{~m}^{3 /}$ ha, such a truck is still viable, although the $\mathrm{C} 4$ truck presents a better economic return to the business in this situation.

The $\mathrm{C} 1$ and $\mathrm{C} 3$ trucks, although presenting positive results, were not presented as the best alternative in any of the evaluated scenarios, being also not feasible at distances above $125 \mathrm{~km}$, regardless of the productivity of the forests.

It should also be pointed out that the productivity of forests is closely related to the feasibility of the

Table 3 - Equations adjusted for the determination of the timber transport cost ( $\mathrm{Y}$, in $\mathrm{R} \$ / \mathrm{ha}$ ), considering the transport distance $(\mathrm{D}$, in $\mathrm{km})$ and the volumetry of forests $\left(\mathrm{V}\right.$, in $\left.\mathrm{m}^{3} / \mathrm{ha}\right)$, for the different types of truck evaluated.

Tabela 3 - Equações ajustadas para a determinação do custo de transporte de madeira (Y, em R\$/ha), considerando a distância de transporte $(\mathrm{D}, \mathrm{em} \mathrm{km})$ e a volumetria das florestas $\left(\mathrm{V}, \mathrm{em} \mathrm{m}^{3} / \mathrm{ha}\right)$, para os diferentes tipos de caminhão avaliados.

\begin{tabular}{|c|c|c|c|c|c|c|}
\hline Truck & Equations & $\mathrm{R}^{2}$ & $\mathrm{CV} \%$ & $\mathrm{R}_{\mathrm{yw}}{ }^{2}$ & $\mathrm{r}^{1 /}$ & $\mathrm{r}^{2 /}$ \\
\hline $\mathrm{C} 1$ & $\mathrm{Y}=\exp \left(1.999+\mathrm{D}^{0.259}+\mathrm{V}^{0.251}\right)$ & 0.986 & 57.11 & 99.65 & $0.825 *$ & $0.508^{*}$ \\
\hline $\mathrm{C} 2$ & $\mathrm{Y}=\exp \left(1.919+\mathrm{D}^{0.258}+\mathrm{V}^{0.250}\right)$ & 0.988 & 57.07 & 99.72 & $0.824 *$ & $0.509 *$ \\
\hline $\mathrm{C} 3$ & $\mathrm{Y}=\exp \left(2.355+\mathrm{D}^{0.254}+\mathrm{V}^{0.246}\right)$ & 0.989 & 54.54 & 99.74 & $0.827 *$ & $0.509 *$ \\
\hline $\mathrm{C} 4$ & $\mathrm{Y}=\exp \left(2.204+\mathrm{D}^{0.249}+\mathrm{V}^{0.244}\right)$ & 0.989 & 52.98 & 98.91 & $0.826^{*}$ & $0.515 *$ \\
\hline
\end{tabular}

On which: * significant at 5\% and $1 \%$ probability, by the " $\mathrm{t}$ " test with $\mathrm{n}-2$ degrees of freedom.

${ }^{1 /}$ Pearson correlation between the variables timber transport cost and transport distance.

${ }^{2 /}$ Pearson correlation between the variables timber transport cost and forest productivity.

Note: The costs estimated by the equations above do not include opening roads and timber loading. 
Table 4 - Timber transport cost (R\$/ha) considering different truck types (TT), forest productivity (FP) and transport distances estimated by the adjusted equations, including costs of opening roads and loading.

Tabela 4 - Custo de transporte de madeira ( $R \$ / h a)$ considerando diferentes tipos de caminhões (TT), produtividade das florestas (FP) e distâncias de transporte estimado pelas equações ajustadas, incluso custos de abertura de estradas e carregamento.

\begin{tabular}{cccccccc}
\hline FP $\left(\mathrm{m}^{3} / \mathrm{ha}\right)$ & $\mathrm{T} \mathrm{T}$ & \multicolumn{5}{c}{ Transport Distance $(\mathrm{km})$} \\
\cline { 2 - 8 } & 25 & 50 & 75 & 100 & 125 & 150 \\
\hline \multirow{3}{*}{150} & $\mathrm{C} 1$ & 3,149 & 4,571 & 5,965 & 7,380 & 8,835 & 10,339 \\
& $\mathrm{C} 2$ & $\underline{\mathbf{2 , 9 5 8}}$ & $\underline{\mathbf{4 , 2 7 1}}$ & $\underline{\mathbf{5 , 5 5 7}}$ & $\underline{\mathbf{6 , 8 6 4}}$ & $\underline{\mathbf{8 , 2 0 7}}$ & $\underline{\mathbf{9 , 5 9 5}}$ \\
& $\mathrm{C} 3$ & 4,486 & 6,199 & 7,850 & 9,506 & 11,191 & 12,916 \\
& $\mathrm{C} 4$ & 3,864 & 5,175 & 6,417 & 7,648 & 8,889 & 10,148 \\
\hline \multirow{3}{*}{200} & $\mathrm{C} 1$ & 4,072 & 5,924 & 7,737 & 9,579 & 11,473 & 13,429 \\
& $\mathrm{C} 2$ & $\underline{\mathbf{3 , 8 2 4}}$ & $\underline{\mathbf{5 , 5 3 3}}$ & $\underline{\mathbf{7 , 2 0 7}}$ & $\underline{\mathbf{8 , 9 0 7}}$ & $\underline{\mathbf{1 0 , 6 5 5}}$ & $\underline{\mathbf{1 2 , 4 6 1}}$ \\
& $\mathrm{C} 3$ & 5,558 & 7,761 & 9,884 & 12,013 & 14,180 & 16,399 \\
& $\mathrm{C} 4$ & 4,472 & 6,420 & 8,011 & 9,587 & 11,175 & 12,787 \\
\hline \multirow{3}{*}{250} & $\mathrm{C} 1$ & 5,034 & 7,336 & 9,590 & 11,881 & 14,235 & 16,667 \\
& $\mathrm{C} 2$ & $\underline{\mathbf{4 , 7 2 5}}$ & $\underline{\mathbf{6 , 8 5 0}}$ & $\underline{\mathbf{8 , 9 3 1}}$ & $\underline{\mathbf{1 1 , 0 4 5}}$ & $\underline{\mathbf{1 3 , 2 1 8}}$ & $\underline{\mathbf{1 5 , 4 6 4}}$ \\
& $\mathrm{C} 3$ & $\mathbf{6 , 6 6 4}$ & 9,376 & 11,988 & 14,609 & 17,276 & 20,008 \\
& $\mathrm{C} 4$ & 5,645 & 7,702 & 9,652 & 11,584 & 13,531 & 15,509 \\
\hline \multirow{3}{*}{300} & $\mathrm{C} 1$ & 6,037 & 8,813 & 11,531 & 14,293 & 17,132 & 20,065 \\
& $\mathrm{C} 2$ & $\underline{\mathbf{5 , 6 6 4}}$ & $\underline{\mathbf{8 , 2 2 6}}$ & $\underline{\mathbf{1 0 , 7 3 6}}$ & $\underline{\mathbf{1 3 , 2 8 6}}$ & $\underline{\mathbf{1 5 , 9 0 6}}$ & 18,614 \\
& $\mathrm{C} 3$ & 7,808 & 1,050 & 14,172 & 17,305 & 20,494 & 23,758 \\
& $\mathrm{C} 4$ & 6,574 & 9,024 & 11,347 & 13,649 & 15,969 & $\underline{\mathbf{1 8 , 3 2 4}}$ \\
\hline
\end{tabular}

Note: The values in bold and underlined correspond to the lowest timber transport cost in each combination of forest productivity, distance and set of trucks evaluated.

Table 5 - Economic indicators for each combination of forest productivity (FP) and transport distances, considering the different truck types (TT) evaluated.

Tabela 5 - Indicadores econômicos para cada combinação de produtividade das florestas (FP) e distâncias de transporte, considerando os diferentes tipos de caminhão (TT) avaliados.

\begin{tabular}{|c|c|c|c|c|c|c|c|c|c|c|c|c|c|}
\hline \multirow{3}{*}{$\frac{F P}{\left(m^{3} / h a\right)}$} & \multirow[t]{3}{*}{ T T } & \multicolumn{12}{|c|}{ Transport Distance $(\mathrm{km})$} \\
\hline & & \multicolumn{2}{|c|}{25} & \multicolumn{2}{|c|}{50} & \multicolumn{2}{|c|}{75} & \multicolumn{2}{|c|}{100} & \multicolumn{2}{|c|}{125} & \multicolumn{2}{|c|}{150} \\
\hline & & $\begin{array}{l}\text { IRR } \\
(\%)\end{array}$ & $\begin{array}{c}\text { NPV } \\
(\mathrm{R} \$ / \mathrm{ha})\end{array}$ & $\begin{array}{l}\text { IRR } \\
(\%)\end{array}$ & $\begin{array}{c}\text { NPV } \\
(\mathrm{R} \$ / \mathrm{ha})\end{array}$ & $\begin{array}{l}\text { IRR } \\
(\%)\end{array}$ & $\begin{array}{c}\text { NPV } \\
\text { (R\$/ha) }\end{array}$ & $\begin{array}{l}\text { IRR } \\
(\%)\end{array}$ & $\begin{array}{c}\text { NPV } \\
(\mathrm{R} \$ / \mathrm{ha})\end{array}$ & $\begin{array}{l}\text { IRR } \\
(\%)\end{array}$ & $\begin{array}{c}\text { NPV } \\
(\mathrm{R} \$ / \mathrm{ha})\end{array}$ & $\begin{array}{l}\text { IRR } \\
(\%)\end{array}$ & $\begin{array}{c}\mathrm{NPV} \\
(\mathrm{R} \$ / \mathrm{ha})\end{array}$ \\
\hline \multirow{4}{*}{150} & $\mathrm{C} 1$ & 16.2 & 2,674 & 129 & 1,474 & 9.1 & 298 & 4.3 & -896 & -2.1 & $-2,124$ & -12.8 & $-3,393$ \\
\hline & $\mathrm{C} 2$ & $\underline{16.6}$ & $\underline{\mathbf{2 , 8 3 5}}$ & $\underline{13.6}$ & $\underline{1,727}$ & $\underline{10.3}$ & $\underline{642}$ & 6.2 & -461 & 0.9 & $-1,594$ & -6.7 & $-2,765$ \\
\hline & $\mathrm{C} 3$ & 13.0 & 1,501 & 8.2 & 52 & 2.1 & $-1,345$ & -6.9 & $-2,745$ & -31.0 & $-4,171$ & -54.9 & $-5,630$ \\
\hline & $\mathrm{C} 4$ & 14.5 & 2,025 & 11.2 & 915 & 7.5 & -137 & 3.0 & $-1,179$ & -3.1 & $-2,230$ & -12.7 & $-3,297$ \\
\hline \multirow{4}{*}{200} & $\mathrm{C} 1$ & 22.4 & 5,418 & 19.1 & 3,863 & 15.5 & 2,340 & 10.8 & 792 & 4.8 & -799 & -4.1 & $-2,442$ \\
\hline & $\mathrm{C} 2$ & $\underline{22.8}$ & $\underline{\mathbf{5 , 6 2 7}}$ & $\underline{19.8}$ & $\underline{4,191}$ & $\underline{16.5}$ & $\underline{2,785}$ & $\underline{12.6}$ & $\underline{1,357}$ & 7.6 & -112 & 0.8 & $-1,629$ \\
\hline & $\mathrm{C} 3$ & 19.7 & 4,120 & 15.2 & 2,264 & 9.7 & 476 & 2.3 & $-1,318$ & 10.7 & $-3,143$ & 47.5 & $-5,013$ \\
\hline & $\mathrm{C} 4$ & 21.2 & 4,804 & 18.0 & 3,389 & 14.6 & 2,048 & 10.6 & 718 & 5.5 & -621 & -1.5 & $-1,981$ \\
\hline \multirow{4}{*}{250} & $\mathrm{C} 1$ & 27.2 & 8,133 & 23.9 & 6,206 & 20.1 & 4,319 & 15.5 & 2,402 & 9.5 & 431 & 1.0 & $-1,604$ \\
\hline & $\mathrm{C} 2$ & $\underline{27.7}$ & $\underline{8,391}$ & $\underline{24.6}$ & $\underline{6,613}$ & $\underline{21.3}$ & $\underline{4,871}$ & $\underline{17.3}$ & $\underline{3,101}$ & $\underline{12.3}$ & $\underline{1,282}$ & 5.7 & -597 \\
\hline & $\mathrm{C} 3$ & 24.9 & 6,714 & 20.4 & 4,437 & 15.1 & 2,243 & 8.2 & 43 & -2.7 & $-2,197$ & 41.8 & $-4,490$ \\
\hline & $\mathrm{C} 4$ & 26.4 & 7,565 & 23.3 & 5,836 & 19.9 & 4,197 & 16.0 & 2,573 & 11.3 & 936 & 5.0 & -726 \\
\hline \multirow{4}{*}{300} & $\mathrm{C} 1$ & 31.2 & 10,816 & 27.8 & 8,500 & 23.9 & 6,231 & 19.2 & 3,927 & 13.1 & 1,557 & 4.4 & -890 \\
\hline & $\mathrm{C} 2$ & $\underline{31.7}$ & $\underline{11,127}$ & $\underline{28.6}$ & $\underline{8,989}$ & $\underline{25.1}$ & $\underline{6,895}$ & $\underline{21.0}$ & $\underline{4,767}$ & 15.9 & $\underline{2,580}$ & 9.2 & 321 \\
\hline & $\mathrm{C} 3$ & $\overline{29.1}$ & 9,278 & $\overline{24.6}$ & $\overline{6,564}$ & $\overline{19.3}$ & $\overline{3,950}$ & $\overline{12.5}$ & $\overline{1,327}$ & 2.2 & $-\overline{1,342}$ & -37.6 & $-4,075$ \\
\hline & $\mathrm{C} 4$ & 30.6 & 10,306 & 27.5 & 8,252 & 24.1 & 6,305 & 20.3 & 4,375 & 15.6 & 2,431 & 9.7 & 457 \\
\hline
\end{tabular}

Note: The values in bold and underlined correspond to the best economic alternative in each combination of forest productivity, distance and set of trucks evaluated.

When IRR $<0$ : Unfeasible in the evaluated conditions

When NPV $<0:$ IRR $<$ that Minimum Attractive Rate à Unfeasible under the evaluated conditions.

Revista Árvore. 2018;42(6):e420608 
forest business, and as productivity decreases and transport distance increases, such sensitivity increases.

\section{DISCUSSION}

The types of trucks evaluated presented different behaviors in relation to the wood transportation cost, leading to different economic-financial results. Several factors have influenced the composition of the timber transport final cost. Affecting differently the performance of each type of truck.

The type of truck to be used in the timber transport will determine the pattern of the necessary forest roads (Cavalli and Grigolato, 2010; Savi et al., 2012). Forest roads with higher traffic volume and vehicles with higher load capacity must be designed and constructed in accordance with more demanding technical requirements, and a more frequent and intensive maintenance should be provided after construction. With the reduction of the traffic volume and the load capacity of the trucks, the technical requirements become simpler, maintenance becomes necessary less frequently and requires less work (Pentek et al., 2011). These premises are in line with the reality observed in the region of this study, where the open roads for light trucks ( $\mathrm{C} 1$ and $\mathrm{C} 2$ ) were structurally simpler than those for other trucks (C3 and C4) and with lower implementation costs.

Still, the environmental factor must be considered. Hayati et al. (2012) affirm that the opening of roads is one of the most expensive and destructive forestry operations from the environmental point of view and, therefore, all transport logistics must be evaluated and optimized to minimize the total cost of road construction and its environmental impact. In this respect, the use of light trucks, where feasible, is able to indirectly represent a reducing agent of environmental impacts by requiring the opening of technically simpler roads.

Another aspect worth mentioning is the timber loading operation. The lower the transport distance, the greater the influence of loading time on the operational cycle and vice versa, with this influence being directly proportional to the size of the truck used (Machado et al., 2009). In fact, Lopes et al. (2016) concluded in their study that the high time consumed by large vehicles during the loading operation compromised the productivity of transport over short distances, a fact that contributes to the encumbrance of this activity. In this way, light trucks (C1 and $\mathrm{C} 2$ ), because they have lower load capacity, require less time to load than medium trucks, and are therefore less sensitive to this operation and have more efficient operational cycles, with such efficiency being inversely proportional to the transport distance.

In forests with lower productivity and shorter distances, the light trucks that were the subject of this study were able to perform faster cycles than the other ones evaluated, which contributed to increase their efficiency and, consequently, to reduce their operational cost. However, with the increase in transport distance and forest productivity, the gains obtained by light trucks in relation to the opening of roads and loading are being diluted, since larger vehicles are more efficient at greater distances and, under this condition, the medium trucks are more advantageous. This was corroborated by Silva et al. (2007), which, by studying the economic radius of the timber transport for different types of vehicles, concluded that the road train presented better performance due to its higher load capacity, with significant cost reduction, being indicated for transport over long distances.

Furthermore, in the analysis of the results of this study, another factor to be highlighted concerns the acquisition value of the trucks evaluated. Light trucks come to have a cost of acquisition up to $30 \%$ lower than the medium trucks and this difference causes a great impact on their operational cost, when accounting for the depreciation cost. According to Barros (2005), the depreciation rate is fixed according to the period during which economic use of the good can be expected in the production of its income, and the depreciation of this good will be proportional to the number of months in which it is part of the asset. Currently in Brazil, vehicles for transporting loads should be depreciated in a maximum of four years (Brasil, 2017). When increasing the efficiency of the light truck, at shorter distances, the depreciation value per kilometer and, consequently, per unit of load, will tend to be lower than that of medium trucks, a factor that in turn will be of great contribution to the decrease in the freight value and, in the case of this study, to decrease the unit value of the timber transport.

Finally, it is necessary to consider the fuel consumption of the trucks evaluated, since there are significant differences between them and this item represents up to $35 \%$ of the freight cost (Oliveira et 
al., 2015). The medium trucks evaluated present, on average, fuel consumption $63 \%$ higher than the light trucks. Although the medium trucks have higher load capacity and consequently lower fuel costs per unit transported, it has been observed that transport is dedicated and the return trips are always without load (Machado et al., 2009), making the advantage of the lower consumption revert to the light trucks in terms of freight cost. This fact is of such importance that Hirsch (2012) and Lindström and Fjeld (2014), when studying the optimization of timber transport, propose that the minimization of the empty truck routes is an important paradigm to be worked with to reduce the timber transport costs.

\section{CONCLUSIONS}

Under the conditions on which this study was conducted and considering timber production in small rural properties, it can be concluded that:

- The use of light trucks, in the $6 \times 2$ version, was the most economically feasible alternative for timber transport in small forest properties, with a maximum feasible distance of $125 \mathrm{~km}$ in forests with productivity of up to $250 \mathrm{~m}^{3} / \mathrm{ha}$.

- In forests with productivity above $300 \mathrm{~m}^{3} / \mathrm{ha}$, the medium truck in the $6 \times 2$ version proved to be the most feasible economic alternative in distances greater than $150 \mathrm{~km}$.

- The light and medium trucks in the $4 \times 2$ version did not prove to be the best economic alternative in any of the evaluated situations.

- The factors transport distance and productivity of the forests have a close correlation with the timber transport cost, economically influencing the profitability of the forest business in a different way for each type of truck evaluated.

\section{REFERENCES}

Alves RT, Fiedler NC, Silva EM, Lopes ES, Carmo FCA. Análise técnica e de custos do transporte de madeira com diferentes composições veiculares. Revista Árvore. 2013;37(5):897-904.

Agência Nacional de Transportes Terrestres ANTT. Planilha de simulação de custo da operação de transporte de cargas. [acessado em: 21 fev. 2017] http://www.antt.gov.br/index.php/ content/view/42064/

Planilha_de_Simulacao_de_Custo_da_Operacao_de_ Transporte_de_Cargas.html.

Barros SF. Contabilidade básica. $2^{a}$ ed. São Paulo: IOB Thomson; 2005.

Basso VM, Jacovine LAG, Griffith JJ, Nardelli A, Alves RR, Souza AL. Programas de fomento rural no Brasil. Pesquisa Florestal Brasileira.

2012;32(1):321-34.

Brasil. Instrução Normativa RFB no 1700 , de 14 de março. de 2017 da Secretaria da Receita Federal. Dispõe sobre a determinação e o pagamento do imposto sobre a renda e da contribuição social sobre o lucro líquido das pessoas jurídicas e disciplina o tratamento tributário da Contribuição para o PIS/Pasep e da Cofins no que se refere às alterações introduzidas pela Lei ${ }^{\circ} 12.973$, de 13 de maio de 2014. Diário Oficial [da República Federativa do Brasil] Brasília, 16 de mar. de 2017.

Cavalli R, Grigolato S. Infuence of characteristics and extension of a forest road network on the supply cost of forest woodchips. Journal of Forest Research. 2010;15(3):202-9.

Corrêa CMC, Malinovski JR, Rollof G. Bases para planejamento de rede viária em reflorestamentos do sul do Brasil. Floresta. 2006;36(2):277-86.

Deimling MF, Parizotto D, Paulek EC, Santos TA. Análise da influência da logística de transportes rodoviários no custo Brasil. Revista de Administração do Unifatea. 2016;13(13):166-88.

Fiedler NC, Barbosa RP, Andreon BC, Gonçalves SB, Silva EN. Avaliação das posturas adotadas em operações florestais em áreas declivosas. Floresta e Ambiente. 2011;18(4):402-9.

Fundação Instituto de Pesquisas Econômicas FIPE. Preço médio de veículos. [acessado em: 21 fev. 2017] http://veiculos.fipe.org.br/.

Oliveira CF, Oliva CV, Passoni DC, Loreti JVC, Stefanini MP, Reijers R. Comparativo do custo de transporte e do frete rodoviário de açúcar para exportação, originado de polos paulistas. Revista de Economia e Agronegócio-REA. 2015;8(1):99-119.

Revista Árvore. 2018;42(6):e420608 
Hayati E, Majnounian B, Abdi E. Qualitative evaluation and optimization of forest road network to minimize total costs and environmental impacts. iForest-Biogeosciences and Forestry. 2012;5(3):121-25.

Hirsch P. Minimizing empty truck loads in round timber transport with tabu search strategies. In: Wang J. Management innovations for intelligent supply chains. Hershey: ICI Global; 2012.

Instituto Nacional de Colonização e Reforma Agrária - INCRA. Classificação dos imóveis rurais. [acessado em: 12 jun. 2017] http:// www.incra.gov.br/tamanho-propriedades-rurais.

Lindström J, Fjeld D. A process perspective on the timber transport vehicle routing problem. Journal of Green Engineering. 2014;4:291-306.

Lopes ES, Vieira TP, Rodrigues CK. Avaliação técnica e de custos do transporte rodoviário com diferentes espécies e sortimentos de madeira. Floresta. 2016;46(3):297-305.

Machado CC, Lopes ES, Birro MHB. Elementos básicos do Transporte Florestal Rodoviário. $2^{\mathrm{a}} \mathrm{ed}$. Viçosa, MG: UFV; 2009.

Moreira JMMAP, Simioni FJ, Santana LJ. Impacto do custo de transporte no risco da rentabilidade florestal na região de Itapeva-SP. Revista Paranaense de Desenvolvimento. 2017;38(132):77-89.
Oliveira RJ, Machado RR, Silva ML, Machado CC. Avaliação dos custos de diferentes sistemas logísticos de suprimento de madeira. Cerne. 2007;13(Suplemento):91-6.

Pentek T, Pièman D, Neveèerel H, Lepoglavec K, Papa I, Potoènik I. Primary forest opening of different relief areas in the republic of Croatia. Croatian Journal of Forest Engineering: Journal for Theory and Application of Forestry Engineering. 2011;32(1):414-6.

Savi AF, Caneppele FL, Oliveira MRC. Custeio de diferentes tipos de transporte rodoviário no setor madeireiro de Itapeva. Floresta e Ambiente. 2012;19(2):147-54.

Seber GAF, Wild CJ. Nonlinear regression. Auckland: Wiley-Blackwell; 2003.

Silva ML, Miranda GM, Cordeiro AS, Leite ES. Custos. In: Machado CC, editor. Colheita florestal. Viçosa, MG: UFV; 2014.

Silva ML, Oliveira RJ, Valverde SR, Machado CC, Pires VAV. Análise do custo e do raio econômico de transporte de madeira de reflorestamentos para diferentes tipos de veículos. Revista Árvore. 2007;31(6):1073-9.

Statsoft, Inc. Statistica for Windows, Release 5.0 Computer program manual. Tulsa: StatSoft; 1995. 